\title{
Impact of Treated Effluents of PSPD, Bhadrachalam on the Survivality and Growth of the Juvenile Snake Head: Channa striatus
}

\author{
T. Suguna* \\ Fisheries Research Station, S.V. Veterinary University, \\ West Godavari, Andhra Pradesh, India \\ *Corresponding author
}

\section{A B S T R A C T}

\begin{tabular}{l} 
K e y w o r d s \\
Godavari water, \\
Treated effluents, \\
PSPD \\
Bhadrachalam, \\
Impact assessment, \\
Survivality, \\
Growth, \\
cannibalism- \\
Channa striatus \\
\hline $\begin{array}{l}\text { Article Info } \\
\text { Accepted: } \\
12 \text { September } 2020 \\
\text { Available Online: } \\
10 \text { October } 2020\end{array}$ \\
\hline
\end{tabular}

ITC paper boards and speciality papers division located at Sarapaka, Bhadrachalam, Khammam, Telangana is among the leading names in the business worldwide and largest manufacturer of paper, paper boards and bleached pulp in south Asia. The waste water generated in the process is treated chemically and biologically before discharge for irrigation. The survivality, Growth and cannibalism, of the juvenile snakehead Channa striatus was evaluated in the waters of Godavari river and treated effluents, PSPD, Bhadrachalam. An enhancement in survivality, growth and reduction in cannibalism was noticed in treated effluent waters, exhibiting their nutritive nature. This investigation infers preliminary information on impact of effluents on aquatic life and also indicates that the juveniles feed mainly on plankton (zooplankton).

\section{Introduction}

Industrial untreated wastewater represents a heavy source of environmental pollution. It affects both the water quality as well as the microbial and aquatic flora. Industrial effluents are characterized by their abnormal water quality. Process water in paper and board mills contains a lot of sugars and lignocelluloses, which support the growth of bacteria, mold and some yeast. Effluents from fertilizer plants contain a higher concentration of potentially toxic wastes rich in Ammonia nitrogen, urea, nitrate-nitrogen orthophosphate - phosphorous which support the growth of algae, yeast and cyanobacteria, cellulolyte bacteria such as Klebsiella pneumoniae and Enterobacter have been isolated from spent water from the paper and pulp industries. The occurrence of these microbes in the effluents lead to excessive oxygen demand loading and also disturb the ecological equilibrium of the receiving waters with much loss of aquatic life and exosystem. 
Industrialization is the index of modernization, which leads to alteration in the physical, chemical and biological properties of environment. Waste water from industries has been tried by several researchers for irrigation. Irrigation of paper mills effluents has shown encouraging results on Oats and Orchard grass (Hashimoto and Yokato, 1965) on paddy, wheat and groundnut (Khambatta and Ketkar, 1969) Hansen et al., (1980) observed that irrigation with effluent is superior than the freshwater in respect of yield of sugarcane and plant characters. Whereas Somashekar et al., (1984) stated that the effluents not only contain nutrients that enhance the growth of crop plant but also have other toxic materials that reduces crop growth and have inhibiting soil characteristics.

In Maize and Mungbean cultivation with paper mill waste water, the root growth and modulation were not affected significantly (Rukhsana Bajwa, 2001). But earlier, Mishra and Sahoo (1989) in comparable studies have reported that paper mill effluents do not induce any inhibitory effects on growth and production of paddy. Similarly field experiments conducted by Vercher et al., (1965) indicate that the production of corn, oats, cowpeas and paddy in soil irrigated with paper mills waste water was at par with well irrigated soil. Yakushenko et al., (1971) successfully utilized paper mill waste water on crops like cucumber, squash and feed grass on sandy soils. Though much of the work is carried in Agriculture but no trails were carried in Aquaculture. Hence a study was carried out on the treated effluents of paper board and speciality paper division, Bhadrachalam, Telangana, to assess the suitability of effluents on Aquaculture, in particular the air breathing fish, Channa striatus.

\section{Materials and Methods}

Fry of $3.5 \mathrm{~cm}$ and 0.8 gms were stocked at the rate of 3000 / acre in Godavari water (control) and treated effluents in ponds at PSPD, ITC, Bhadrachalam and reared for three months (Fig. 2 and 3).

Depth of water was maintained $50-75 \mathrm{~cm}$. Fertilization of ponds (0.085 ha) was not done. Boiled and minced chicken offal is served as feed as per the body weight. The elemental analysis and water quality parameters of the treated effluents are done by standard methods as per the Manuel of MITCON, 2003, Shinde et al., 1997 and recorded regularly. The qualitative plankton analysis and growth performance are recorded fortnightly. The rate of survivality and cannibalism are recorded periodically and harvested after 3 months.

\section{Results and Discussion}

The analytical results such as physico chemical, biological and elemental analysis of the treated effluents are as follows:

The color of effluent was dark brown and it smelt like rotten egg (sulphurous) (Fig. 1). The $\mathrm{pH}$ of effluent ranged from 7.2-8.1. The effluent was slightly alkaline with TDS and Sulphate contents. The remaining parameters were present in optimum levels (Table 1). The elements, $\mathrm{Na}, \mathrm{K}, \mathrm{Ca}, \mathrm{Mg}$, and $\mathrm{Mn}$ were in lower concentrations where as, heavy metals like $\mathrm{Cd}, \mathrm{Pb}, \mathrm{Ni}, \mathrm{Hg}, \mathrm{Cr}, \mathrm{Co}$ and $\mathrm{Ag}$ were not detectable (Table 2).

Blue green algae and green algae are predominantly seen in phytoplankton. Where as Clado cerans and rotifers are dominating in zooplankton (Table 3). The growth performance of juveniles reared in effluents is greater (Fig. 5a, 5b and 8) than that reared in Godavari waters (Fig. 5a, 5b and 7). The rate of survivality is higher in effluent treated waters than in juveniles reared in Godavari 
waters (Fig. 4). The rate of cannibalism is declining in juveniles reared in treated effluent treated waters where as it is enhancing in juveniles reared in Godavari waters (Fig. 6).

Table.1 Physico chemical analysis of PSPD treated effluents

\begin{tabular}{|c|c|c|}
\hline Sl. No. & Factor & Values \\
\hline 1. & Colour & Dark brown \\
\hline 2. & Odour & $\begin{array}{l}\text { Sulphurous / smelling like } \\
\text { rotten egg. }\end{array}$ \\
\hline 3. & Temperature ${ }^{\circ} \mathrm{C}$ & $24-36^{\circ} \mathrm{C}$ \\
\hline 4. & $\mathrm{pH}$ & $7.2-8.2$ \\
\hline 5. & Conductivity $\left(\mathrm{dsm}^{-1} / \mathrm{cm}\right)$ & 2.1 \\
\hline 6. & Alkalinity $\left(\mathrm{mg} \mathrm{L}^{-1}\right)$ & 256 \\
\hline 7. & Total hardness $\left(\mathrm{mg} \mathrm{L}^{-1}\right)$ & 352 \\
\hline 8. & Total suspended solids $\left(\mathrm{mg} \mathrm{L}^{-1}\right)$ & 81 \\
\hline 9. & Total Dissolved solids $\left(\mathrm{Mg} \mathrm{L}^{-1}\right)$ & 1052 \\
\hline 10. & Dissolved Oxygen $\left(\mathrm{Mg}^{-1}\right)$ & $1.9-4.5$ \\
\hline 11. & $\mathrm{COD}\left(\mathrm{Mg} \mathrm{L}^{-1}\right)$ & 152 \\
\hline 12. & $\mathrm{BOD}\left(\mathrm{Mg} \mathrm{L}^{-1}\right)$ & 23 \\
\hline 13. & Chlorides as $\mathrm{CL}\left(\mathrm{Mg} \mathrm{L}^{-1}\right)$ & 158 \\
\hline 14. & Sulphates as $\mathrm{So}_{4}\left(\mathrm{Mg} \mathrm{L}^{-1}\right)$ & 580 \\
\hline 15. & Phosphorous ( $\left.\mathrm{Mg} \mathrm{L}^{-1}\right)$ & 1.8 \\
\hline
\end{tabular}

Table.2 Elemental analysis of PSPD treated effluents

\begin{tabular}{|c|c|c|}
\hline Sl. No. & Element & Concentrations ${\mathbf{~ M g ~} \mathbf{M L}^{-\mathbf{1}}}^{\mathbf{}}$ \\
\hline $\mathbf{1 .}$ & $\mathrm{K}$ & 23.81 \\
\hline $\mathbf{2}$. & $\mathrm{Ca}$ & 127.05 \\
\hline $\mathbf{3 .}$ & $\mathrm{Mg}$ & 21.53 \\
\hline $\mathbf{4 .}$ & $\mathrm{Fe}$ & 1.14 \\
\hline $\mathbf{5 .}$ & $\mathrm{Mn}$ & 0.19 \\
\hline $\mathbf{6 .}$ & $\mathrm{Zn}$ & 0.37 \\
\hline $\mathbf{7 .}$ & $\mathrm{Cu}$ & 0.14 \\
\hline $\mathbf{8 .}$ & $\mathrm{Na}$ & 175.3 \\
\hline $\mathbf{9 .}$ & $\mathrm{Cd}$ & $\mathrm{ND}$ \\
\hline $\mathbf{1 0 .}$ & $\mathrm{Pb}$ & $\mathrm{ND}$ \\
\hline $\mathbf{1 1 .}$ & $\mathrm{Ni}$ & $\mathrm{ND}$ \\
\hline $\mathbf{1 2 .}$ & $\mathrm{Hg}$ & $\mathrm{ND}$ \\
\hline $\mathbf{1 3}$ & $\mathrm{Cr}$ & $\mathrm{ND}$ \\
\hline $\mathbf{1 4}$ & $\mathrm{Co}$ & $\mathrm{ND}$ \\
\hline $\mathbf{1 5}$ & $\mathrm{Ag}$ & $\mathrm{ND}$ \\
\hline
\end{tabular}


Table.3 Biological analysis of PSPD treated effluents

\begin{tabular}{|c|l|l|}
\hline Sl. No. & \multicolumn{1}{|c|}{ Plankton } & \multicolumn{1}{|c|}{ Zooplankton } \\
\hline $\mathbf{1 .}$ & Diatoms & Protozoa - No existence \\
\hline $\mathbf{2 .}$ & Blue green algae & Rotifers - appreciable in number \\
\hline $\mathbf{3 .}$ & Green algae & $\begin{array}{l}\text { Cladocerens - extra ordinary rise in } \\
\text { population of moina. }\end{array}$ \\
\hline $\mathbf{4 .}$ & Euglenoids & Copepods - Fairly good \\
\hline
\end{tabular}

Fig.1 Effluent water

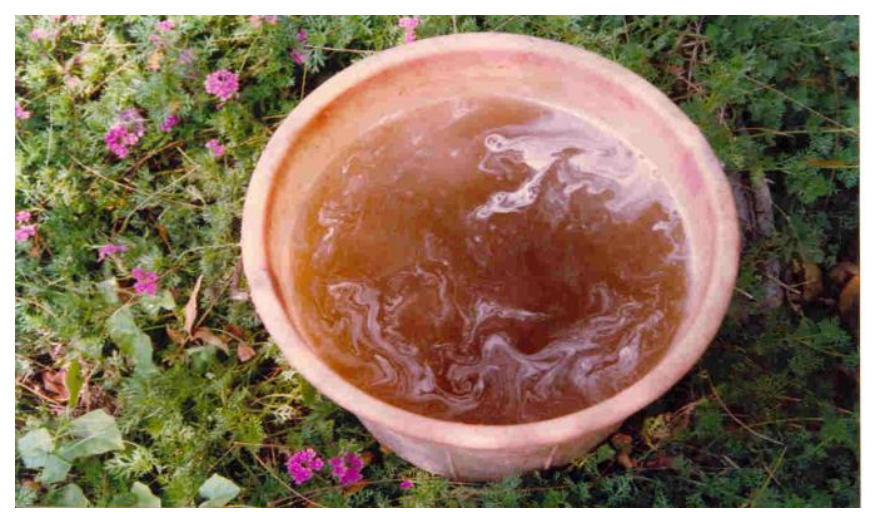

Fig.2 Experimental ponds

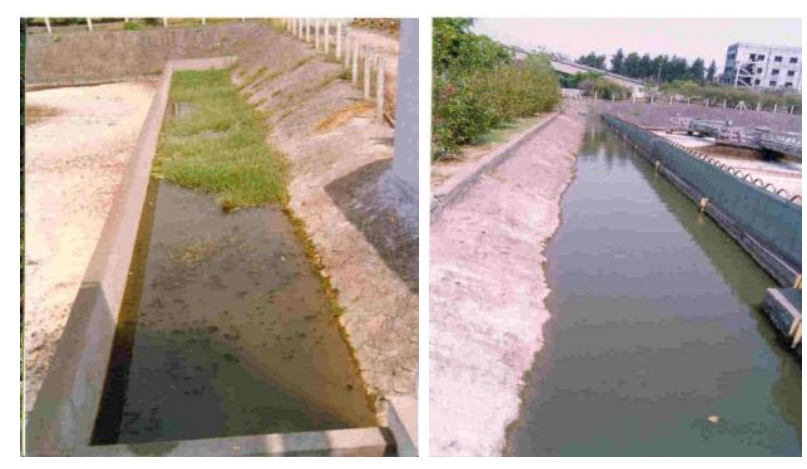

Fig.3 Fry for stocking

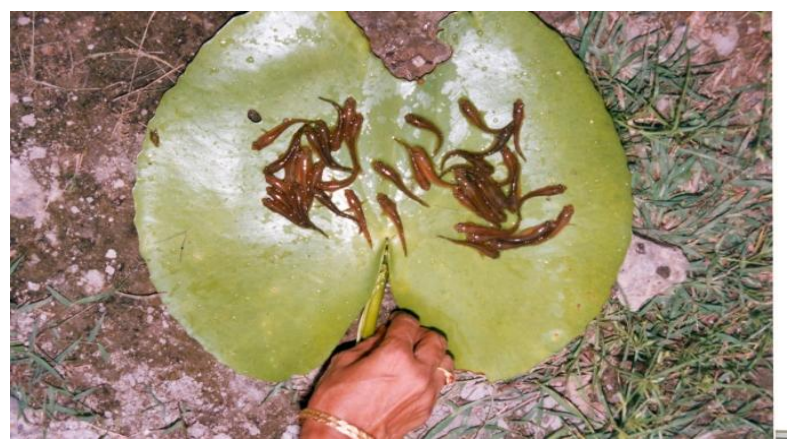


Int.J.Curr.Microbiol.App.Sci (2020) 9(10): 1585-1591

Fig.4 Rate of survivality

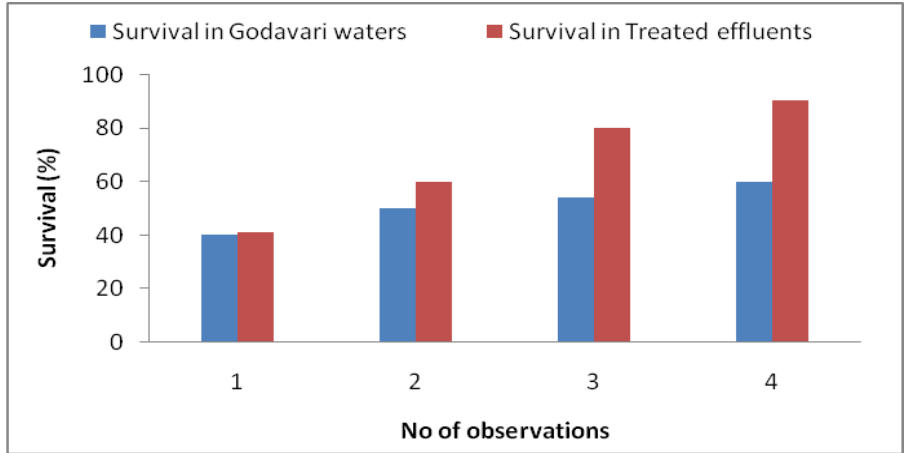

Fig.5a Growth performance: Variance in length

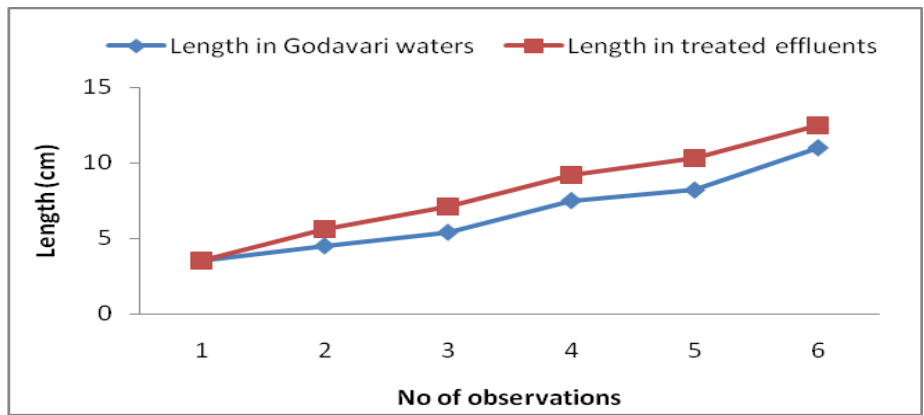

Fig.5b Growth performance: Variance in weight

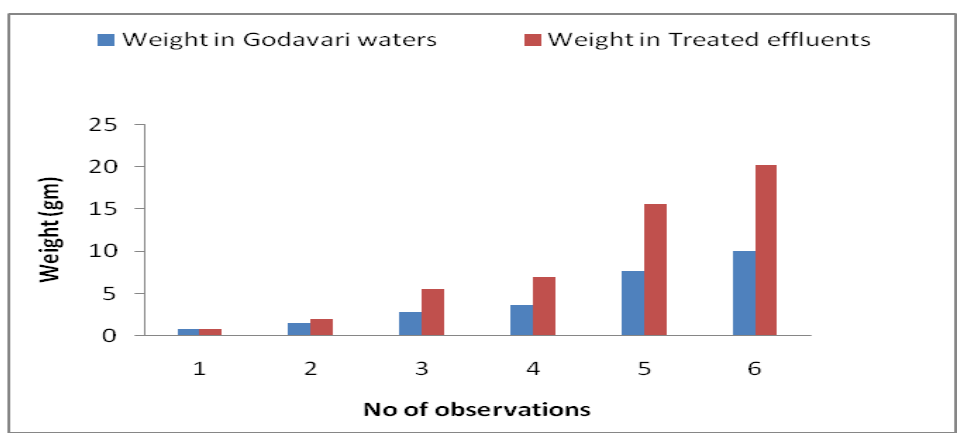

Fig.6 Rate of cannibalism

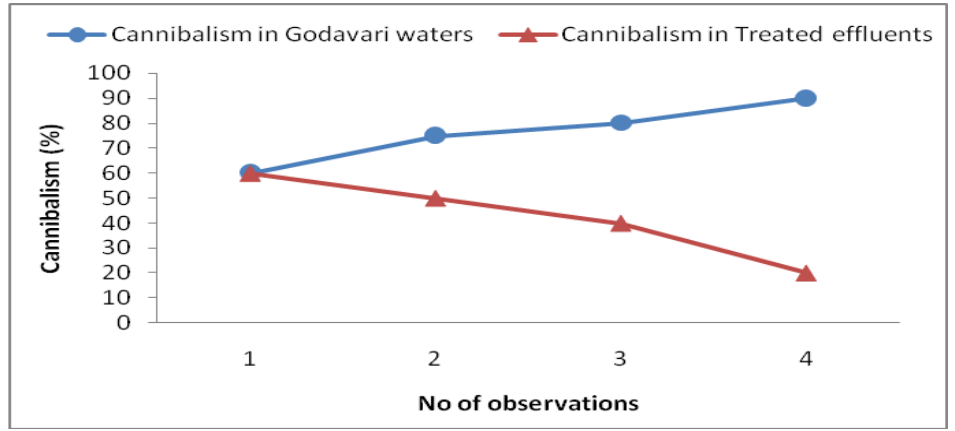


Fig.7 Harvested fingerlings (control)

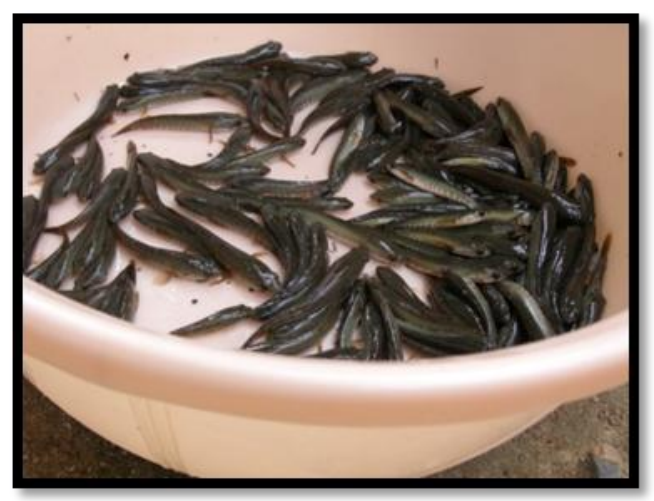

Fig.8 Harvested fingerlings (effluents)

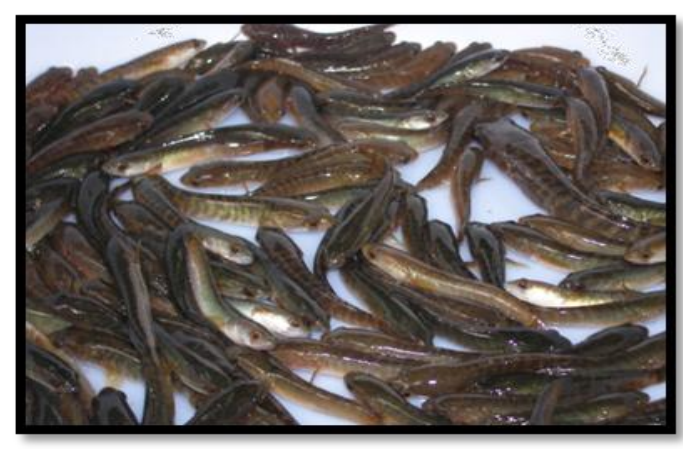

In view of the encouraging results obtained, it infers that the plankton (phytoplankton and zooplankton) are fairly high in treated effluents which speaks of possible use of effluents as important resource for rearing of fish, as effluents are providing live fish food organisms. It is needless to mention that plankton are the choice fish food organisms (Fig. 7 and 8).

Hence it can be concluded that the treated effluents from PSPD, Bhadrachalam, industry are nutritious and encouraged the growth of juvenile, snakehead Channa striatus.

\section{References}

Hansen, E.A., D.H. Dawson and D.N. Tolsted, 1980. Irrigation of intensively cultured plantations with paper mill effluent. Tappi, 63: 139-143.
Hashimoto and Yokoto, 1965: Edaphological studies on the utilization of waster pulp liquor. J. Sci. Soil Menura, Tokyo, 36: $231-234$.

Khasambatta, S.J. and Ketkar, C.M., 1969. Present scheme for treatment and utilization of paper mill effluent on land for irrigation. Presented in symposium of problems connected with disposal of waste from various industries round about Poona Nov. 2930, 1969.

Mishra, P.C. and S. Sahoo, 1989. Agropotentiality of paper mill waste water. In: Soil pollution and soil organisms (P.C. Mishra, ed). PP - 97119 Ashish Publishing House, New Delhi.

Rukhsana Bajwa, Uzma Basher and Arshad Javaid: Sustainability of paper mill waste water affected soil for Maize and 
Mungbean cultivation. Pak. J. Bot. 33 special issue, 2001.

Shinde, D.D., D.G. Thorat, P.S. Gunjal and S.R. Kuchekar (1997). Physico Chemical aspects of pollution in Godavari River at Nasik. I. Aqua, Biol, $12(1 \& 2) 85$.

Somasekhar, R.K., M.T.G. Gowda, S.L.N. Shettigar and K.P. Srinath, 1984, The effect of industrial effluents on crop plants. Indian J. Environ Hlth., 26: 136-146.
Vercher, B.D., M.B. Sturgis, O.D. Curtis, A.L. Nugent and L.L. Mecormick, 1965. Paper mills water for crop irrigation and its effects on the soil. Bull. La agric. Exp. Stn. No. 604, p. 46.

Yukushenko, I.K., I.Y. Kazantav and V.G. Ovsyannikava 1971. Waste water from sulphate pulp production and their use of irrigation. Abster 7930n, Chen, Astr. 74.

\section{How to cite this article:}

Suguna, T. 2020. Impact of Treated Effluents of PSPD, Bhadrachalam on the Survivality and Growth of the Juvenile Snake Head: Channa striatus. Int.J.Curr.Microbiol.App.Sci. 9(10): 1585-1591. doi: https://doi.org/10.20546/ijcmas.2020.910.189 